\title{
Filter paper cortisol profiles in secondary adrenocortical insufficiency
}

\author{
J S Sieratzki, C Gompels, K Poyser, J Beaman, D C L Savage
}

\begin{abstract}
The use of filter paper four point 24 hour cortisol profiles in the diagnosis and management of secondary adrenocortical deficiency was examined. Eighteen children with familial short stature and isolated growth hormone deficiency had normal 24 hour and morning plasma cortisol concentrations measured. Eight of 11 children with multiple pituitary hormone deficiencies had evidence of hypocorticalism despite previously normal baseline cortisols or responses to insulin hypoglycaemia or tetracosactrin. Nine of 11 children with hypopituitarism on replacement treatment (4.9-12.5 $\mathrm{mg} / \mathrm{m}^{2} /$ day) had satisfactory concentrations of cortisol, though morning cortisols were often low. Filter paper profiles are a simple, inexpensive, and relatively non-invasive way of managing children with suspected hypocorticalism and of monitoring their treatment.

(Arch Dis Child 1995; 73: 351-353)
\end{abstract}

Keywords: hypocorticalism, 24 hour cortisol profiles, filter paper assay.

There is no agreement on the best test for the diagnosis of adrenocortical insufficiency secondary to hypothalamic pituitary disease. The measurement of basal plasma cortisol ${ }^{12}$ and dynamic tests of pituitary or adrenocortical reserve $\mathrm{e}^{3-8}$ can all misrepresent physiological adrenocortical secretion. Mean plasma cortisol concentrations from multiple sampling over a period of time is a reliable $\operatorname{method}^{9}$ but is too invasive to become part of clinical practice. However, the mean plasma cortisol concentration in four equally spaced samples closely approximates in normal subjects the mean concentration measured on a single sample obtained by continuous aspiration or from multiple sampling over a 24 hour period. ${ }^{10} \mathrm{We}$ have therefore examined filter paper cortisol profiles using four blood samples over a 24 hour period to assess adrenocortical function and to determine the adequacy of steroid replacement treatment in children treated for adrenocortical insufficiency.

\section{Subjects and methods}

The children and adolescents, whose ages ranged from 2-19 years, attended endocrine clinics in the South Western Regional Health Authority. With the exception of those on steroid replacement treatment they were presumed on laboratory tests to have normal adrenocortical function. Four groups were examined: six (four boys, two girls) were normal children with short stature (group 1), 12 (11 boys, one girl) had presumed isolated growth hormone deficiency (group 2), 11 (seven boys, four girls) had multiple pituitary hormone deficiencies (group 3), and 11 (six boys, five girls) with multiple pituitary hormone deficiencies were on cortisol supplementation (group 4).

The families were taught to use the lancets and filter papers to complete the profiles. The first capillary blood spot was taken before 8 $\mathrm{am}$, another around midday, one at $6 \mathrm{pm}$, and a final sample the next morning before $8 \mathrm{am}$. Those children on hydrocortisone supplements took the blood before their morning and evening doses of hydrocortisone. To examine reproducibility the profiles were repeated two weeks later. The children were asked not to take blood samples if they were unwell. All the profiles were completed at home and the filter papers posted to the laboratory and stored till processing in batches.

The laboratory cost of a single four point profile in a batch of four profiles $(£ 19)$ compared favourably with a tetracosactrin (Synacthen; Ciba) or insulin tolerance test (ITT) in which three cortisol samples were assayed in each test $(£ 14)$. Both tetracosactrin and ITT require additional clinical costs and appreciable service time.

Cortisol in blood spots was measured by adaptation of the Farmos serum cortisol radioimmunoassay kit. The ${ }^{125} \mathrm{I}$-cortisol tracer and antiserum were premixed for at least one hour, $100 \mu \mathrm{l}$ was then added to $6 \mathrm{~mm}$ blood spot discs and incubated at $37^{\circ} \mathrm{C}$ for 90 minutes. Separation was by polyethylene glycol precipitation. Blood spot cortisol results were compared with plasma cortisol concentrations measured using the Farmos kit according to the recommended protocol. There was good correlation between the two methods, although the blood spot results tended to be slightly higher than plasma. The correlation coefficient was 0.897 and slope 1.28 on 48 samples.

The detection limit of the assay was 50 $\mathrm{nmol} /$. Interassay precision was $13 \cdot 2 \%$ at 100 $\mathrm{nmol} / \mathrm{l}$ and $4.3 \%$ at $770 \mathrm{nmol} / /$. The stated cross reactivity of the antiserum at $50 \% \mathrm{~B} / \mathrm{Bo}$ is cortisol $100 \%$, prednisolone 15 , cortisone $20 \%$, 11-deoxycortisol $15 \%$, and corticosterone $2 \%$.

The quality of the blood spots was generally good with blood fully soaked through the filter paper to give two discs of greater than $6 \mathrm{~mm}$ diameter for each time point.

Median rather than mean values were determined for both the 24 hour four point plasma
Correspondence to: Dr Savage.

Accepted 22 May 1995 
Table 1 Median morning and 24 hour plasma cortisol concentrations

\begin{tabular}{|c|c|c|c|c|}
\hline & $\begin{array}{l}\text { Group } 1 \\
(n=6)\end{array}$ & $\begin{array}{l}\text { Group } 2 \\
(n=12)\end{array}$ & $\begin{array}{l}\text { Group } 3 \\
(n=11)\end{array}$ & $\begin{array}{l}\text { Group } 4 \\
(n=11)\end{array}$ \\
\hline Condition & Short stature & $\begin{array}{l}\text { Isolated growth hormone } \\
\text { deficiency }\end{array}$ & Hypopituitary & $\begin{array}{l}\text { Hypopituitary } \\
\text { on treatment }\end{array}$ \\
\hline \multicolumn{5}{|c|}{$\begin{array}{l}\text { Median (range) } \\
\text { cortisol (nmol/l) }\end{array}$} \\
\hline $\begin{array}{l}24 \text { Hour } \\
\text { Morning }\end{array}$ & $\begin{array}{l}225(199-303) \\
341(180-466)\end{array}$ & $\begin{array}{l}221(139-407) \\
301(193-697)\end{array}$ & $\begin{array}{l}118(<50-239) \\
155(<50-412)\end{array}$ & $\begin{array}{l}274(<50-790) \\
109(<50-2000)\end{array}$ \\
\hline
\end{tabular}

cortisol concentration and morning cortisols to allow for the $<50 \mathrm{nmol} / 1$ values which though mainly present in groups 3 and 4 would tend to bias their means upwards.

The project was approved by the Bristol and District Health Authority research ethics committee.

\section{Results}

There was no significant difference between the two profiles in the children in groups 1 to 3 for either the mean morning cortisols or the mean 24 hour plasma cortisol concentration (Wilcoxon matched pairs signed ranks). The children on cortisol supplementation (group 4) had a greater intertest variability. Comparison of the results in groups 1 and 2 confirmed that they did not differ significantly (two tailed Mann-Whitney $U$ test) and that these two groups could be combined.

The median 24 hour plasma cortisol concentration using both test days are shown in table 1 . The combined median (2 SD) for those with presumed normal adrenocortical function in group 1 and 2 was 225 (114) $\mathrm{nmol} / \mathrm{l}$. Taking a figure less than $2 \mathrm{SD}$ below the median $(<111 \mathrm{nmol} / \mathrm{l})$ as a possible indicator of adrenocortical insufficiency no patient in group 1 or 2 had such a result. Two children in group 3 had concentrations $<111 \mathrm{nmol} / 1$ on both test days and five additional children had a single test day concentration of plasma cortisol $<111 \mathrm{nmol} / /$. The median morning plasma cortisols of both test days are shown in table 1 . Taking a morning concentration of $<200$ $\mathrm{nmol} / \mathrm{l}$ as a possible indicator of adrenocortical insufficiency ${ }^{11}$ no child in groups 1 or 2 had both morning cortisols on any one profile $<200 \mathrm{nmol} / \mathrm{l}$, although five had one concentration marginally $<200 \mathrm{nmol} / 1$ (median 193 $\mathrm{nmol} / \mathrm{l}$, range $180-199 \mathrm{nmol} / \mathrm{l})$. Five children in group 3 had all four morning cortisols in

Table 2 Cortisol data on seven children with suspected hypocorticalism

\begin{tabular}{|c|c|c|c|c|c|c|c|c|}
\hline \multirow{2}{*}{$\begin{array}{l}\text { Patient } \\
\text { No }\end{array}$} & \multicolumn{2}{|c|}{ Cortisol (nmoll) } & \multirow{2}{*}{$\begin{array}{l}\text { Interval } \\
\text { to profile } \\
\text { (years) }\end{array}$} & \multicolumn{4}{|c|}{ Capillary cortisol profile (nmoll) } & \multirow{2}{*}{$\begin{array}{l}\text { Median } \\
\text { plasma cortisol } \\
\text { (nmoll) }\end{array}$} \\
\hline & Basal & Peak & & 0800 & 1200 & 1800 & 2400 & \\
\hline 1 & 708 & - & 3 & $\begin{array}{r}187 \\
54\end{array}$ & $\begin{array}{l}106 \\
<50\end{array}$ & $\begin{array}{r}81 \\
<50\end{array}$ & $\begin{array}{r}101 \\
52\end{array}$ & $\begin{array}{r}104 \\
51\end{array}$ \\
\hline 2 & 907 & - & 7 & $\begin{array}{r}110 \\
92\end{array}$ & $\begin{array}{r}85 \\
<50\end{array}$ & $\begin{array}{l}67 \\
68\end{array}$ & $\begin{array}{l}198 \\
108\end{array}$ & $\begin{array}{l}98 \\
80\end{array}$ \\
\hline 3 & 274 & $485^{\star}$ & 5 & $\begin{array}{l}<50 \\
<50\end{array}$ & $\begin{array}{l}<50 \\
<50\end{array}$ & $\begin{array}{l}<50 \\
<50\end{array}$ & $\begin{array}{l}<50 \\
<50\end{array}$ & $\begin{array}{l}<50 \\
<50\end{array}$ \\
\hline 4 & 204 & $630^{\star}$ & 4 & $\begin{array}{r}121 \\
87\end{array}$ & $\begin{array}{r}144 \\
<50\end{array}$ & $\begin{array}{r}52 \\
<50\end{array}$ & $\begin{array}{r}145 \\
<50\end{array}$ & $\begin{array}{r}133 \\
<50\end{array}$ \\
\hline 5 & 103 & $590+$ & $0 \cdot 1$ & $\begin{array}{r}101 \\
84\end{array}$ & $\begin{array}{l}75 \\
63\end{array}$ & $\begin{array}{l}81 \\
70\end{array}$ & $\begin{array}{r}97 \\
133\end{array}$ & $\begin{array}{l}89 \\
77\end{array}$ \\
\hline 6 & 322 & - & $0 \cdot 1$ & $\begin{array}{l}201 \\
212\end{array}$ & $\begin{array}{r}76 \\
<50\end{array}$ & $\begin{array}{l}<50 \\
<50\end{array}$ & $\begin{array}{r}248 \\
97\end{array}$ & $\begin{array}{r}139 \\
74\end{array}$ \\
\hline 7 & 234 & $703 *$ & 2 & $\begin{array}{r}293 \\
92\end{array}$ & $\begin{array}{l}130 \\
101\end{array}$ & $\begin{array}{r}86 \\
<50\end{array}$ & $\begin{array}{l}279 \\
190\end{array}$ & $\begin{array}{r}205 \\
97\end{array}$ \\
\hline
\end{tabular}

^ITT. †Tetracosactrin test. both profiles $<200 \mathrm{nmol} / 1$ (median $95 \mathrm{nmol} / \mathrm{l}$ ), range $50-198 \mathrm{nmol} / \mathrm{l}$ ) and three others had one or both morning cortisols on a single profile $<200 \mathrm{nmol} / \mathrm{l}$ (median $122 \mathrm{nmol} / \mathrm{l}$, range 84-190 nmol/1).

A median 24 hour plasma cortisol concentration $<111 \mathrm{nmol} / \mathrm{l}$ on a single profile had a sensitivity of $18 \%$ (95\% confidence interval (CI) $3 \%$ to $52 \%$ ) and a specificity of $100 \%$ (95 CI $82 \%$ to $100 \%$ ) but if either of the two profiles was used this was $64 \%(95 \%$ CI $31 \%$ to $89 \%$ ) and $100 \%$ (95\% CI $82 \%$ to $100 \%$ ). . Two consecutive morning cortisols $<200$ $\mathrm{nmol} / 1$ on a single profile had a sensitivity of $45 \%(95 \%$ CI $17 \%$ to $77 \%)$ and specificity of $100 \%$ (95\% CI $82 \%$ to $100 \%)$. If either of the two profiles was used the sensitivity was $64 \%$ (95\% CI $31 \%$ to $89 \%$ ) and specificity $100 \%$ (95\% CI $82 \%$ to $100 \%$ ).

Combining the data for the median plasma cortisol concentrations $>111 \mathrm{nmol} / 1$ on a single profile and a morning cortisol $>200$ $\mathrm{nmol} / \mathrm{l}$ on at least one occasion on a single profile then no child in group 1 or 2 could be regarded as having hypocorticalism. Five children in group 3 had definite evidence of hypocorticalism and two others were suspect with at least one mean cortisol $<111 \mathrm{nmol} / 1$ and one morning cortisol $<200 \mathrm{nmol} / \mathrm{l}$ on a single profile (table 2 ).

There was agreement between previous tests of adrenocortical function and the results of the filter paper profile analysis in the 18 children in groups 1 and 2 who all had previously normal cortisol responses to ITT $(n=16)$ or normal random cortisols $(n=2)$. In group 3, of the four patients with normal filter paper profiles one had had a normal random cortisol, two normal cortisol responses to ITT, but the fourth had had a poor response to ITT some two months earlier. The remaining seven children with evidence of hypocorticalism had either had a normal cortisol response to ITT $(n=3)$, tetracosactrin $(n=1)$, or normal random cortisols $(322,708$, and $907 \mathrm{nmol} / \mathrm{l})$ from $0 \cdot 1$ to 7 years earlier (average 3.4 years) (table 2).

Nine of 11 children in group 4 had satisfactory concentrations of cortisol through the day, though many had concentrations $<50$ $\mathrm{nmol} / \mathrm{l}$ before their morning cortisol tablet was taken. The dose of hydrocortisone given twice daily was from $4.9-12.5 \mathrm{mg} / \mathrm{m}^{2} /$ day (mean 8.9 $\mathrm{mg} / \mathrm{m}^{2} /$ day). The two children with low cortisol concentrations were on 4.8 and 6.9 $\mathrm{mg} / \mathrm{m}^{2} /$ day.

\section{Discussion}

There are a number of tests for the assessment of adrenocortical hypofunction but none are entirely satisfactory, particularly when the insufficiency is secondary to hypothalamicpituitary disease. ${ }^{10}$ Basal cortisol concentrations may be of little help as they are decreased only in advanced hypothalamic pituitary disease. $^{2}$ Insulin hypoglycaemia cannot be recommended because of its unpleasant side effects and the associated stress which may significantly overestimate the gland's normal secretory pattern. The short tetracosactrin test 
though less unpleasant may give normal results in secondary adrenocortical hypofunction, 478 though recently it has been suggested that a low dose Synacthen test might be more discriminatory. ${ }^{12}$ The discrepancies in the ITT and tetracosactrin test occur as both tests measure the adrenal gland's reserves and these do not always reflect its nyctohemeral secretory ability.

A recent review article examining these tests in association with 24 and 48 hour plasma cortisol profiles with blood taken either half hourly or by continuous sampling, clearly showed that they could misrepresent the activity of the adrenal cortex. ${ }^{10}$ Furthermore four blood samples taken at six hourly intervals over a 24 hour period gave a similar mean cortisol concentration to that of more invasive sampling. ${ }^{10}$ The children in our study with presumed normal adrenocortical function (groups 1 and 2) had similar median cortisol concentrations to the results obtained by Streeten and others. ${ }^{91013}$ However, some children with presumed normal adrenocortical function (group 3) as assessed by previous insulin hypoglycaemia, tetracosactrin or basal cortisol measurement, had four point profiles that were distinctly abnormal. Our study suggests that a morning plasma cortisol $<200$ $\mathrm{nmol} / \mathrm{l}$ combined with a 24 hour median concentration $<111 \mathrm{nmol} / 1$ on a four point filter paper plasma cortisol profile indicates possible adrenocortical insufficiency. Two profiles in sequence increase the sensitivity of the test.

Home based filter paper profiles may have advantages over random cortisol concentrations as a screening method for adrenocortical insufficiency. The stress of a visit to hospital or venepuncture can invalidate random cortisol results, while filter paper capillary blood profiles at home may minimise the problem. There is also the additional information of two morning cortisols on each 24 hour profile and the combined mean four point cortisol concentrations. We already use filter paper profiles for the measurement of 17-hydroxyprogesterone in the management of congenital adrenal hyperplasia where they have proved acceptable and relatively unstressful to the children.

Many children with hypopituitarism do not have a complete anterior pituitary dysfunction, though this may appear over the years. This is particularly true in children who have received cranial irradiation ${ }^{14}$ and probably also those who have received total body irradiation; in them the filter paper profile appears to be an ideal method for an annual assessment. In the absence of a simple, relatively non-invasive, and accurate method of assessing adrenocortical function the decision regarding cortisol supplementation has often been based on an outdated ITT or tetracosactrin test or is made empirically. Symptoms of cortisol deficiency can be subtle or absent. Only one of the children in our study with evidence of hypocorticalism had, on direct questioning, symptoms suggestive of cortisol deficiency. However, with cortisol replacement treatment a number of their parents have commented on their child's improved wellbeing though we cannot exclude this being a placebo effect.
Cortisol profiles are useful in the monitoring of children treated with hydrocortisone and our study confirms the small dose of hydrocortisone that is needed to maintain generally satisfactory concentrations of plasma cortisol. The profiles also highlight the low morning cortisols that are often present in these children. Many paediatricians still give too large a replacement dose of hydrocortisone even though the normal adrenocortical secretory rate is known to be approximately 7-9 $\mathrm{mg} / \mathrm{m}^{2} /$ day. ${ }^{15} 16$ These higher doses are probably a reflection of an often quoted figure of $12.5 \mathrm{mg} / \mathrm{m}^{2} /$ day and advice that double that dose should be given because of variable absorption after oral administration. ${ }^{17}$

There is probably no best test for hypothalamic adrenal hypofunction but physiological tests are preferable to pharmaceutical stimuli. ${ }^{10}$ We have found filter paper cortisol profiles a simple, cheap, relatively non-invasive method of assessing adrenocortical function in children. We now use them in our region in children suspected of, or who might have, progressive loss of adrenocortical function and in assessing the adequacy of cortisol replacement treatment.

We are grateful to Ms Linda Hunt, statistician, Institute of Child Health, Bristol for statistical advice.

1 Wand GS, Ney RL. Disorders of the hypothalamicpituitary-adrenal axis. Clinical Endocrinology and Metabolism 1985; 14: 33-53.

2 Forest MG. Adrenal steroid deficiency status. In: Brook CGD, ed. Clinical paediatric endocrinology. Oxford: Blackwell, 1989: 368-406.

3 Tsatsoulis A, Shalet SM, Harrison J, et al. Adrenocorticotrophin (ACTH) deficiency undetected by standard dynamic tests of the hypothalamicpituitary-adrenal axis. Clin Endocrinol (Oxf) 1988; 28: 225-32.

4 Borst GC, Michenfelder HJ, O'Brian JT. Discordant cortisol response to exogenous ACTH and insulin hypoglycemia in patients with pituitary disease. $N$ Engl f Med 1982; 306: 1462-4.

5 Cunningham SK, Moore A, McKenna TJ. Normal cortisol response to corticotrophin in patients with secondary response to corticotrophin in patients with second
adrenal failure. Arch Intern Med 1983; 14: 947-76.

6 Stewart PM, Corrie J, Seckl JR, et al. A rational approach for assessing the hypothalamic-pituitary axis. Lancet 1988; $\mathrm{i}$ : 1208-10.

7 Clayton RN. Diagnosis of adrenal insufficiency. BMF 1989; 298: 27

8 Mansell P, Scott VL, Logan RF, et al. Secondary adrenocortical insufficiency. BMF 1933; 307: 253-4.

9 Zadik L, de Lacerda L, de Carmargo LAH, et al. A comparative study of urinary 17 -hydroxycortico-steroids, urinary free cortisol, and the integrated concentration of plasma cortisol. F Clin Endocrinol Metab 1980; 51: 1099

10 Streeten DHP, Anderson GH, Dalakos TG, et al. Normal and abnormal function of the hypothalamicpituitary-adrenocortical system in man. Endocr Rev 1984; 5: 371-94.

11 Hagg E, Asplund K, Lithner F. Value of basal plasma cortisol assays in the assessment of pituitary-adrenal insufficiency. Clin Endocrinol (Oxf) 1987; 26: 221-6.

12 Crowley S, Hindmarsh PC, Honour JW, et al. Reproducibility of the cortisol response to stimulation Reproducibility of the cortisol response to stimulation
with a low dose of ACTH (1-24): the effect of basal cortisol levels and comparison of low-dose with high-dose cortisol levels and comparison of low-dose with high-dose

13 Hellman L, Nakada F, Curt J, et al. Cortisol is secreted episodically by normal man. $\mathcal{F}$ Clin Endocrinol Metab 1970; 30: 411 .

14 Lam KSL, Tse VKC, Wang C, et al. Early effects of cranial irradiation on hypothalamic-pituitary function. $\mathcal{f}$ Clin Endocrinol Metab 1987; 64: 418-24.

15 New MI, Seaman MP. Secretion rate of cortisol and aldosterone precursors in various forms of congenital adrenal hyperplasia. F Clin Endocrinol Metab 1970; 30: 361-71.

16 Linder BL, Esteban NV, Yergey AL, et al. Cortisol production rates in childhood and adolescence. $\mathcal{F}$ Pediatr 1990; 117: 892-6.

17 Heazelwood NJ, Galligan JP, Cannell GR, et al. Plasma relative bioavailability. $\mathrm{Br} f \mathrm{Clin}$ Pharmacol 1984; 17: 55-9. 